Proceedings of the 2018 International Scientific Conference 'Economic Sciences for Agribusiness and Rural Economy' No 2, Warsaw, 7-8 June 2018, pp. 161-166

\title{
WELFARE FARMS IN POLAND AS AN EXAMPLE OF ENTREPRENEURIAL ACTIVITIES IN RURAL AREAS
}

\author{
Monika Wojcieszak, $\mathrm{PhD}^{1}$ \\ Faculty of Economic and Social Sciences, Poznań University of Life Sciences
}

\begin{abstract}
The purpose of the paper was to present the importance of welfare farms in Poland as a social element of mutual relations, connections and co-operation in local and regional development. The concept of welfare farms is characterised in the study and the main idea of their formation is presented. Examples of welfare farms in Poland as part of the first pilot project known as 'Zielona opieka - gospodarstwa opiekuńcze w woj. kujawsko-pomorskim' (Green care: welfare farms in the Kujawsko-Pomorskie voivodeship) have also been presented. It was also pointed out that social farming plays an increasingly important role in the contemporary development of rural areas. The paper was compiled using the desk research method and a classical analysis of documents was used. The choice of methods was determined by the availability of source materials, some of which were of primary or secondary nature (social farming literature, reports and public statistic documents). This paper also pointed to the fact that welfare farms are increasingly becoming a popular form of social service in rural areas. It also testifies to the entrepreneurship of farmers, because they offer not only accommodation and catering, but also care on their farms.
\end{abstract}

Keywords: welfare farms, rural areas, agri-tourism

JEL codes: Q10, Q19, Q13

\section{INTRODUCTION}

One of the challenges for contemporary Poland is the unfavourable demographic trend which includes a significant increase in the number of older people in society. Poland is the fastest ageing country in the European Union (Eurostat, 2018). The ageing society is a problem that is increasingly being undertaken by many researchers, e.g.: Press.UK, Di Iacovo and O'Connor (2009); Sempik, Hine and Wilcox (2010); Hassinka, Hulsink and Grin (2014); Matysiak and Michalska (2016); Balińska and Wojcieszak (2017); Kalinowski and Kozera-Kowalska (2017) stressed that the elderly are untapped human capital. Their activation and presentation of interesting and attractive proposals for self-realisation are important. It is also necessary to design specific social security models for rural areas for this group of people. Welfare farms may be an answer to this aspect and are created in the area of multifunctional agriculture; the form of such management is part of social farming due to the specificity of activity. Przezbórka-Skobiej (2015) noted that multifunctional agriculture produces other products in addition to food and raw materials as well as goods and services for the processing industry which there is a demand for. Multifunctional development

${ }^{1}$ Corresponding author: Wojska Polskiego 28, 60-637 Poznań, Poland, mwoj@up.poznan.pl, +48 787280095 
of the countryside and rural areas may contribute to the fact that these areas accept and perform functions other than agricultural ones, i.e. tourist, residential, industrial functions, and currently also caring functions (Sadowski el al., 2015). Attention is also paid to the social aspect and therefore to social farming, which is defined by the European Economic and Social Committee as an approach combining two concepts, i.e. multifunctional agriculture and social services which means healthcare at the local level, contributing to the improvement of the well-being and social integration of people with special needs.

\section{THEORETICAL BACKGROUND}

The idea of the formation of welfare farms goes back to the second half of the 20th century. They first appeared in Europe in the post-war period in the mid1990s. These types of farms have enjoyed considerable interest in many countries, including the Netherlands, France, Norway, Italy, Belgium, Germany, Austria, UK and the United States (Di Iacovo, 2014). Many researchers dealing with the social aspect in rural areas, i.e. Hassink and Dijk (2006); Hine, Peacock and Pretty (2008); Haubenhofer et al. (2010); Sempik, Hine and Wilcox (2010), have noticed that in the nomenclature of literature, care in rural areas is variously called e.g. green care, agriculture for health, green care in agriculture; however, a common integral feature of these terms is to provide and ensure care. There are many definitions of welfare farms available in the literature; however, it is often referred to as social farming combining a range of services, including day or long-term care with elements of agricultural production and rearing (Hassink and Dijk, 2006; Dessein, 2007; Haubenhofer et al., 2010; Williams and Randal-Smith, 2011; Leck et al., 2014). In general, term 'care farming' is a universal concept that reflects the diversity of operations and activities combined with the support of processes related to social well-being (Dessein, 2007). In Poland, the concept of creating welfare farms has been introduced recently. Care for the elderly, youth or children will constitute a new product that can be offered by agricultural and agri-tourist farms. Seniors, children, adolescents and adults can use the services offered on the care farm facilities. The main task of these operators are activities based on ensuring contact with nature and staying in a natural environment that exerts a good influence on the well-being of humans (Dessein and Bock, 2010). Welfare farms can offer a form of rehabilitation and integration through participation in the performance of simple activities, e.g. taking care of animals, gardening, carrying out manual work jointly or developing contacts with people like them.

\section{MATERIALS AND METHODS}

Secondary data used for the purpose of this paper was retrieved from online sources, including materials prepared by the EU, state government and local government administration and other entities (including organisations of local communities in rural areas) involved in the development of social farming, and in particular in the creation and management of welfare farms. The analysis also included reports and studies prepared for the implementation of projects financed from EU funds as well as data from official statistics. The data method that was used was desk research using tabular and graphical presentation.

\section{RESULTS AND DISCUSSION}

More and more often, social agriculture is provided as one of the alternatives to classical agriculture, especially in European Union countries. The interest in such activity is the result of growing awareness and understanding of the role of agriculture and rural resources. Many authors (Krzyżanowska, 2010; Sikora, 2012; Bogusz and Kmita-Dziasek, 2015; Wiatrak, 2015; Zawadka, 2015; Sznajder, 2017) emphasise the importance of rural areas as places which can play a key role in improving the social, physical and the mental well-being of citizens. For farmers, social farming is an opportunity to provide new services and to expand and diversify their activities and to have a multifunctional role in society (Kamiński, 2017). This type of integration in the field of social and agricultural activities can provide farmers and their household dwellers with additional sources of income and contribute to improving the image of agriculture in the eyes of the public. 
According to the forecasts of the Central Statistical Office, the population of Poland will be only 37.8 million in 2020 , and only 36 million people in 2035. The information contained in numerous statistical studies indicates that in addition to the systematic decline in the population in Poland, there is also progressive ageing of the population. In the face of these changes, it was noticed that rural areas have enormous potential that can be used and which the elderly, single people, children and the youth can take advantage of. Farmers wanting to obtain non-agricultural income undertake entrepreneurial activities. One of such enterprises is establishing welfare farms. The main reasons for the development of care services provided on the basis of farms in rural and suburban areas may be the demand for care services and the search for new sources of income by farms. At the same time, it should be noted that the emergence of care farms in rural areas affect two aspects, i.e. the problem of an ageing population and multifunctional rural development (Fig. 1).

The main clients of this type of facility may be elderly people, people with mental disabilities, people with reduced mobility, those leaving penitentiary institutions, children, young people, the unemployed and people who are burned out professionally (Kamiński, 2017). In Poland, in order for the farmer or householder to run a welfare farm, he/she must fulfil the condition regarding the appropriate legal form admissible in Polish legal legislation. In Poland, private farms are run by natural persons. In the case of taking up care activities, it is necessary to establish a new legal form i.e. running a welfare farm in the form of a social economy (foundation, association) or running a welfare farm as part of an economic activity. The frequency and duration of care provided by the farm may vary. Four forms of care can be distinguished: temporary stay without accommodation on the farm,

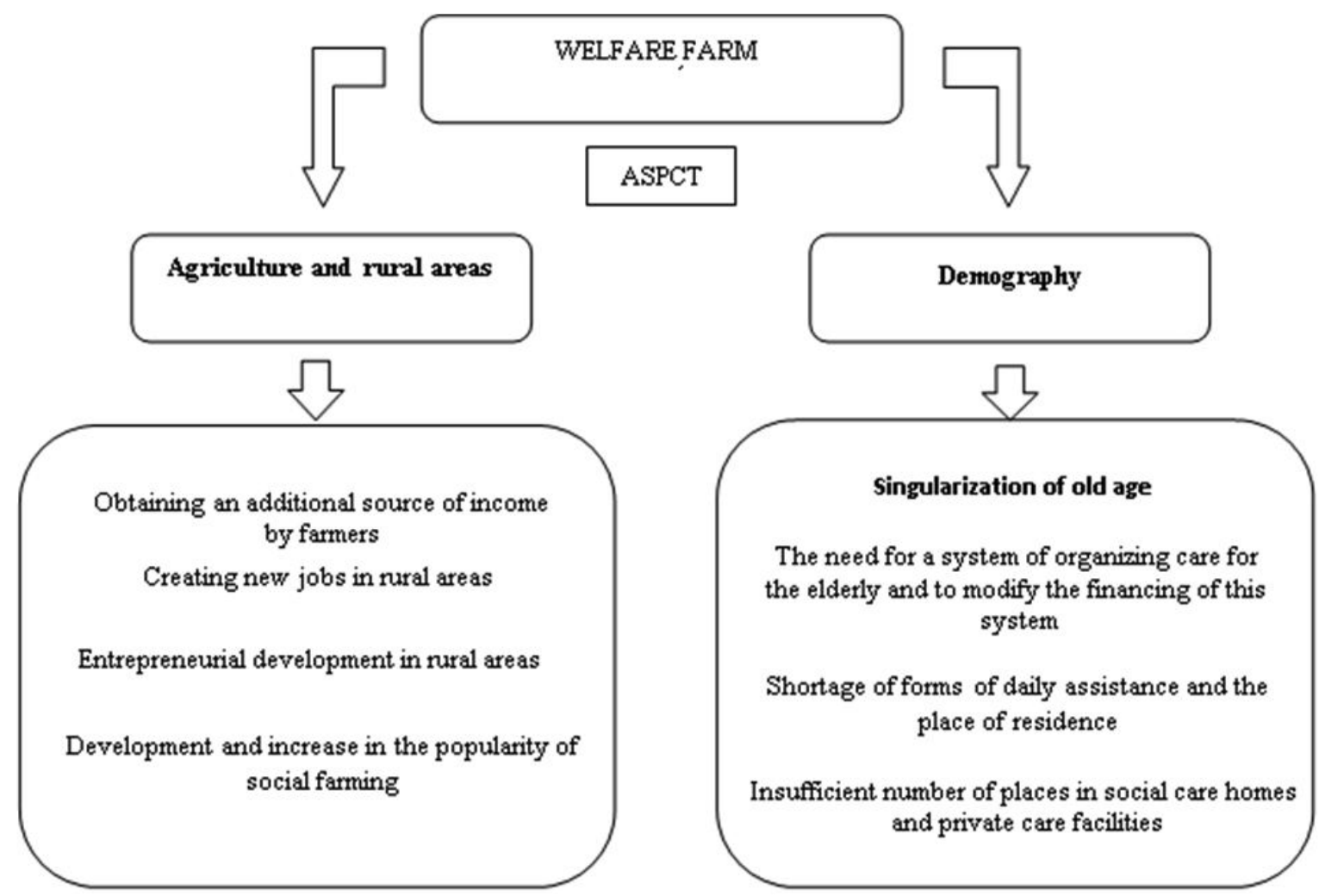

Figure 1. Reasons for the development of welfare farms

Source: own compilation based on materials by Król (2017). The idea of the development of social farming, including welfare farms in the world, Agricultural Advisory Center in Brwinów, Kraków branch. 
temporary residence with accommodation, continuous stay without accommodation, continuous stay with accommodation. It should also be pointed out that welfare farms are an increasingly popular dimension of the entrepreneurial and social initiative of farmers. Awareness of an ageing society and the desire to obtain additional sources of financing have caused farmers modelling themselves on Dutch farmers to provide care services. In Poland, the first welfare farms were created as part of the project entitled 'Zielona opieka
- gospodarstwa opiekuńcze w woj. kujawsko-pomorskim' (Green care: welfare farms in the Kujawsko-Pomorskie voivodeship). The project is currently being implemented by public institutions, i.e. Kujawsko-Pomorski Ośrodek Doradztwa Rolniczego w Minikowie (Kuyavian-Pomeranian Agricultural Advisory Center in Minikowo) in partnership with Bory Tucholskie, the Local Action Group, as part of the Regional Operational Program of the Kujawsko-Pomorskie voivodeship for the years 2014-2020 (Table 1).

Table 1. Welfare farms in Poland as part of the project known as 'Zielona opieka - gospodarstwa opiekuńcze w woj. kujawsko-pomorskim' (Green care: welfare farms in the Kujawsko-Pomorskie voivodeship) [selected examples]

\begin{tabular}{|c|c|c|c|c|}
\hline $\begin{array}{l}\text { Welfare } \\
\text { farm } \\
\text { (name) }\end{array}$ & $\begin{array}{l}\text { Scope of care } \\
\text { (care hours) }\end{array}$ & $\begin{array}{l}\text { Rooms used } \\
\text { by person under care }\end{array}$ & $\begin{array}{l}\text { Short characteristics } \\
\text { of the person under care }\end{array}$ & $\begin{array}{l}\text { Classes conducted } \\
\text { on the farm } \\
\text { for the persons under care }\end{array}$ \\
\hline Wysoka & \multirow{3}{*}{$\begin{array}{l}\text { day care from } \\
\text { Monday to } \\
\text { Friday, from } \\
8.00 \text { to } 16.00\end{array}$} & $\begin{array}{l}\text { living room with fireplace } \\
\text { rest room } \\
\text { kitchen } \\
\text { dining room } \\
\text { bathroom }\end{array}$ & $\begin{array}{l}\text { dependent persons from all } \\
\text { dispensary groups }\end{array}$ & $\begin{array}{l}\text { needlework } \\
\text { small library } \\
\text { exercise equipment }\end{array}$ \\
\hline Mokre & & $\begin{array}{l}\text { living room with kitchenette } \\
\text { rest room } \\
\text { bathroom } \\
\text { toilet }\end{array}$ & $\begin{array}{l}\text { people with physical } \\
\text { disabilities, moving on } \\
\text { crutches and walking frames } \\
\text { people with food allergies } \\
\text { people who require a special } \\
\text { diet due to illness, e.g. } \\
\text { diabetes, celiac disease }\end{array}$ & $\begin{array}{l}\text { manual classes } \\
\text { small library } \\
\text { pets/animals } \\
\text { needlework }\end{array}$ \\
\hline Lubiewice & & $\begin{array}{l}\text { living room connected to the } \\
\text { dining room and kitchenette } \\
\text { rest room } \\
\text { bathroom }\end{array}$ & $\begin{array}{l}\text { people with physical } \\
\text { disabilities, moving on } \\
\text { crutches and walking frames } \\
\text { people with sight dysfunction } \\
\text { people with food allergies } \\
\text { and requiring a specialist diet } \\
\text { due to illness (e.g. diabetes) }\end{array}$ & $\begin{array}{l}\text { Workshops (Christmas } \\
\text { decorations } \\
\text { decoupage, scrap booking } \\
\text { needlework and home } \\
\text { decorating }\end{array}$ \\
\hline
\end{tabular}

Source: Own compilation on the basis of webpage information http:/www.opieka.kpodr.pl/pl/zielona-opieka/profile-gospodarstw [Accessed 27.05.2018]. 
As part of the project, fifteen welfare farms were created in five districts: Świecie, Mogilno, Brodnica, Wąbrzeźno and Tuchola. These welfare farms provide care for 156 people (as at the end of 2017). The project involves developing care in small groups; currently, they are 5-person groups. Home care is provided to dependent persons by a qualified carer and volunteer, from Monday to Friday, 8 hours a day. Farms will provide: basic care, organising the time of the persons under care, minimum one hot meal and access to drinks and small meals, as well as access to newspapers and books ${ }^{2}$.

\section{CONCLUSIONS}

In Poland, taking initiatives to create care homes as a new trend related to the so-called social farming is a little-known phenomenon. The essence of welfare farms presented in the paper is an ever-changing tourist offer of stay in rural areas and testifies to the entrepreneurship of farmers. As shown in the study, welfare farms are part of the concept of the so-called social farming which combines the idea of multifunctional and service-social agriculture with care at the local level. The idea of a welfare farm may in the future be a great development opportunity for many farms, because, firstly, it can generate additional income for these farms, and secondly, developing social services in rural areas can be an effective way to overcome many negative socio-economic phenomena.

\section{REFERENCES}

1. Bogusz, M., Kmita-Dziasek, E. (2015). Zagrody edukacyjne jako przykład innowacyjnej przedsiębiorczości na obszarach wiejskich. (Educational farms as an example of innovative entrepreneurship in rural areas]. In: Kamińska, W. (ed.) Innowacyjność w turystyce wiejskiej a nowe możliwości zatrudnienia na obszarach wiejskich. [Innovation in rural tourism and new employment opportunities in rural areas]. Komitet Przestrzennego Zagospodarowania Kraju PAN, 158, pp. 155-166.
2. Dessein, J. (2007). Farming for Health, Proceedings of the Community of Practice Farming for Health. ILVO, Ghent.

3. Dessein, J., Bock, B. (2010). The Economics of Green Care in Agriculture. Loughborough University Press, Loughborough.

4. Di Iacovo, F. (2014). Agriculture and social sustainability. In Sustainability of the Agri-Food System, Strategies and Performances. Universitas Studiorum, Mantova.

5. Hassink, J., Dijk, M. (2006). Farming for Health: GreenCare Farming Across Europe and the United States of America. Dordrecht, Springer.

6. Hassinka, J., Hulsink, W., Grin, J. (2014). Farming with care: the evolution of care farming in the Netherlands. NJA - Wageningen Journal of Life Sciences, 68, pp. $1-11$.

7. Haubenhofer, D.K., Elings, M., Hassink, J., Hine, R. (2010). The development of green care in Western European countries. Explore, 6, pp. 106-111.

8. Hine, R., Peacock, J., Pretty, J. (2008). Care farming in the UK - Evidence and Opportunities. University of Essex. Report for the National Care Farming Initiative (NCFI).

9. Kalinowski, S., Kozera-Kowalska, M. (2017). Samoocena sytuacji dochodowej ludności wiejskiej o niepewnych dochodach [Self-assessment of the income situation of the rural population with uncertain income]. Handel Wewnętrzny, 4 (369), 1, pp. 110-121.

10. Kamiński, R. (2014). Gospodarstwa opiekuńcze jako alternatywna ścieżka rozwoju gospodarstw agroturystycznych [Welfare farms as an alternative path for the development of agri-tourism farms]. Kujawsko-Pomorski Ośrodek Doradztwa Rolniczego w Minikowie, Minikowie.

11. Król, J. (2017). Idea rozwoju rolnictwa społecznego, w tym gospodarstw opiekuńczych na świecie [The idea of the development of social farming, including welfare farms in the world]. Centrum Doradztwa Rolniczego w Brwinowie Oddział w Krakowie, Kraków.

12. Krzyżanowska, K. (2010). Przedsiębiorczość na obszarach wiejskich. Stan i perspektywy rozwoju [Rural entrepreneurship. Current condition and development perspectives]. Wydawnictwo SGGW, Warszawa.

13. Leck, Ch., Evans, N., Upton, D. (2014). Agriculture - Who cares? An investigation of 'care farming' in the UK. Journal of Rural Studies, 34, pp. 313-325.

\footnotetext{
${ }^{2}$ Agroturytyka.kpodr.pl webpage http://www.agroturystyka.kpodr.pl/pl/gospodarstwa-opiekuncze?eq[gosp_rol13]=1 [Accessed 28.05.2018].
} 
14. Press.UK, Di Iacovo, F., O’Connor, D. (2009). Supporting Policies for Social Farming in Europe. Progressing Multifunctionality in Responsive Rural Areas. ARSIA.

15. Przezbórka-Skobiej, L. (2015). Polityka rozwoju obszarów wiejskich Unii Europejskiej a rozwój turystyki wiejskiej [The European Union's rural development policy and the development of rural tourism]. In: Kamińska, W., Wilk-Grzywna, M. (eds.) Turystyka wiejska i agroturystyka. Nowe paradygmaty dla XXI wieku [Rural tourism and agritourism. New paradigms for the 21 st century]. Studia KPZK, 162, pp. 9-25.

16. Sadowski, A., Poczta, W., Szuba-Barańska, E., Beba, P. (2015). Modele gospodarstw rolnych w państwach Unii [Farm models in EU countries]. Wieś i Rolnictwo, 3 (168), pp. 43-62.

17. Sempik, J., Hine, R., Wilcox D. (2010). Green Care. A Conceptual Framework. Loughborough University, Loughborough.
18. Sikora, J. (2012). Agroturystyka. Przedsiębiorczość na obszarach wiejskich [Agri-tourism. Rural entrepreneurship]. C.H. Beck, Warszawa.

19. Sznajder, M. (2017). Metropolitan Commuter Belt Tourism, Routledge Taylor \& Francis, Oxon.

20. Wiatrak, A.P. (2015). Analiza kierunków rozwoju obszarów wiejskich w UE oraz uwarunkowań ich zmian [Analysis of the directions of rural areas development in the EU and the conditions of their changes]. Zeszyty Naukowe. Uniwersytet Ekonomiczny w Poznaniu, 150, pp. 160-175.

21. Wojcieszak, M., Balińska, A. (2017). Aktywność turystyczna seniorów [Tourist activity of senior citizens]. Wydawnictwo WSB w Toruniu, Toruń.

22. Zawadka, J. (2015). Agroturystyka jako forma wypoczynku w opinii osób w średnim wieku w Polsce [Agritourism as a form of recreation in the opinion of middle-aged people in Poland]. Rocznki Naukowe SERiA, 18 (3), pp. 421-426. 